\title{
Stronger through Diversity
}

Citation for published version (APA):

Letschert, R. (2016). Stronger through Diversity. Maastricht University.

https://doi.org/10.26481/spe.20160901rl

Document status and date:

Published: 01/09/2016

DOI:

10.26481/spe.20160901rl

Document Version:

Publisher's PDF, also known as Version of record

\section{Please check the document version of this publication:}

- A submitted manuscript is the version of the article upon submission and before peer-review. There can be important differences between the submitted version and the official published version of record.

People interested in the research are advised to contact the author for the final version of the publication, or visit the DOI to the publisher's website.

- The final author version and the galley proof are versions of the publication after peer review.

- The final published version features the final layout of the paper including the volume, issue and page numbers.

Link to publication

\footnotetext{
General rights rights.

- You may freely distribute the URL identifying the publication in the public portal. please follow below link for the End User Agreement:

www.umlib.nl/taverne-license

Take down policy

If you believe that this document breaches copyright please contact us at:

repository@maastrichtuniversity.nl

providing details and we will investigate your claim.
}

Copyright and moral rights for the publications made accessible in the public portal are retained by the authors and/or other copyright owners and it is a condition of accessing publications that users recognise and abide by the legal requirements associated with these

- Users may download and print one copy of any publication from the public portal for the purpose of private study or research.

- You may not further distribute the material or use it for any profit-making activity or commercial gain

If the publication is distributed under the terms of Article $25 \mathrm{fa}$ of the Dutch Copyright Act, indicated by the "Taverne" license above, 
Prof.dr.mr. Rianne Letschert Rector Magnificus Maastricht University

\section{Stronger through Diversity}




\section{Inaugural speech, September 1, 2016}

\section{Stronger through Diversity}

Honorable Minister of Education, Major of the city of Maastricht, distinguished guests, dear colleagues, dear students and friends. This is the first time that I am standing high up on this pulpit - or in fact any pulpit.. - in this well respected church wearing the gown of Maastricht University with the chain of office around my neck. A bit uneasy I can assure you...

Maastricht University with its 40 years of existence is one of the youngest universities of the Netherlands. Beautifully located in the heart of Maastricht, a city with a long history and a great tradition. The origin of its name, Mosa Trajectum, refers to its role of a location where people cross borders and connect and explore other regions. This has largely contributed to the development and identity of Maastricht and it has given the city the reputation of being internationally oriented with a broad diversity of cultures. This is not always easy, in particular in a period of time where the attraction of the importance of diversity is under pressure. And yet, diversity is the answer to many of our concerns, also for an organization such as a university.

Although Maastricht University is still young, higher education in Maastricht dates back to the Illustere School Maastricht founded already in 1682 and therefore, as Luc Soete already remarked during his inaugural speech given in 2012, Maastricht University in tradition counts as one of the oldest universities of the Netherlands.

This ladies and gentlemen, brings me to Luc Soete, outgoing rector of our university. Let me start by thanking you Luc for your beautiful and insightful speech. It outlines in an excellent way the period you were rector; the many things you have achieved and the issues you have encountered while being in office. You have done a lot for Maastricht University and I know our university community is grateful for all the contributions you made in the past four years. Many of your colleagues will allude to these achievements and thank you in person later today. We only met a few months ago, and how I wished we had met earlier on in our lives. Your sharp mind and wise observations, your modest and kind character, and not to forget your humor, are exemplary. I feel humble and a bit nervous to succeed such a great man. I very much appreciated how you introduced me into some of the rituals and secrets - only a rector should know - of Maastricht University over the past few months.

Dear Luc, I hope that you will find the time and peace of mind to refocus entirely on the field of economic models and theories, your scientific area of expertise. Within the academic community the job of rector is considered merely as an interruption of one's scientific activities. And fully in line with this fine tradition you will stay at our university and return to your academic work. This in fact is not a real return since you managed to continue your academic work while being a rector. Again a true example! I wish you many fruitful and productive years to come and look forward to our continuing cooperation.

\section{And who am I?}


And here I am, the smiley power lady as the Volkskrant headlined when they wrote a profile on me a few months ago. Or... the lady from Tilburg University, breaking many of your traditions when it comes to appointing a Rector Magnificus and in the eyes of some even breaking the law... Why did they appoint her to become rector of our university, was a thought that must have crossed the mind of many of you?

Allow me, ladies and gentlemen, to say a few introductory words about myself so that you know who I am and where I come from. I studied law at Tilburg University, the University of Amsterdam and the University of Montpellier. I received my PhD in 2005 on a study on the Impact of Minority Rights Mechanisms. Since 2005, I worked in the field of victimology and international law, at INTERVICT, the International Victimology Institute at Tilburg University.

Victimology is a field that is interdisciplinary almost by definition. At first it mainly focused on victims of conventional crime such as murder, theft or rape. At INTERVICT we opened up a new angle of research by concentrating on persons who are victims of serious human rights violations or international crimes such as genocide or war crimes. The VIDI project that I and my colleagues were granted last year focuses on how to redress harm of victims of such horrific crimes or to put in legal terms how to implement the right to reparations'. Neither the impact of the right to reparations on the experience of victims of such crimes nor the mechanisms by which this impact is supposed to be reached have been subject to much scrutiny. Assessing both the value as well as the limits of the law and legal institutions in situations where the rule of law is violated in all its fundamentals, is what drives me as a researcher. It brought me to countries such as Lebanon, Rwanda, Pakistan, India, South-Africa, and greatly influenced my view on the law and its institutions, and taught me important life lessons.

Another professional development that I would like to share with you is my membership of the Young Academy of the Dutch Royal Society of Arts and Sciences. In 2013, I was appointed as member and as of April 2015 I was allowed to chair this fine group of outstanding young and ambitious talents. This, ladies and gentlemen, has been a groundbreaking experience for me. The members of the Young Academy constitute a unique community of young scientists from all scientific disciplines that is critical and cooperative at the same time. And I am very proud that Maastricht University contributes to the Academy with some of their best people.

Without exception, members of the Young Academy focus on broad issues; the academic system; the relationship between science and society; our responsibilities in this respect and the ways forward we should explore. During all these discussions I experienced an attitude within the Young Academy that was geared toward deeper understanding and synthesis, and without exception members contribute to the discussion in an altruistic and outgoing manner; never defending their personal agenda; never limited by the straight-jacket of their scientific discipline or their home university or faculty. The diversity of insights that they bring to the table is enormous and this further convinced me that diversity can make science and the university as a whole, strong, innovative and resilient.

\section{Why do I want to be a rector?}

During the past months I was a visiting guest here for a few days a week, having introductory meetings with several colleagues, and two of the most frequently asked 
questions were "Why do you want to become a rector and what about your research and education?" During these encounters, some referred to the position of rector as a vague and insignificant job. One of our colleagues welcomed me with the remark that he was happy to see me as his new rector but at the same time he said that he hadn't the faintest idea what a rector does for a living. I answered: neither do I, but we will find out!

On a serious note, although I have great passion for academic research and teaching and I will strive to remain involved in both - I realized at a certain moment, eating oysters in Bretagne, that key drivers for me are not how to improve my $\mathrm{H}$ index, or how to obtain more personal grants. The reason why I want to get up in the morning is to engage with academic life and get involved in all its aspects, to make a valuable contribution to academic growth and ... to try to make a difference for students, staff and society at large. I see the university as a Laboratory where we are allowed to think about the future, where we have a great responsibility to invest in our students to assist them in becoming responsible citizens and leaders in their field, and where the knowledge we create through our research may shape our future and address the challenges we are faced with.

Another reason for driving to Maastricht early in the morning is that I have great concerns that next generations of young scholars who come after me face many more difficulties to enter and make an academic career. I am eager to see where we, as universities, can change the current atmosphere which is getting increasingly negative and at times even cynical. This not only relates to staff becoming more pressurized, but also to students, who become more and more outspoken, and demand high quality education, and rightly so. I want to create a connectivity with the student population and together continuously work to increase the quality of our education. Thereby also calling upon their responsibilities as students, because in my view, rights and responsibilities go hand in hand. Access to higher education is not a mandatory act but a gift and a privilege. At this point I want to especially address our students. I hope that you are aware of your unique position being able to receive the best possible education, having the opportunity to build your character, develop your personality, and prepare for a position to contribute to society. And you can do this at one of the finest universities in the country enjoying academic life as much as possible.

Dear audience, you may expect from me the presentation of a concrete ten step strategic plan, but I won't. Some of you probably are disappointed now... After all, wasn't it Maastricht University's independent, famous newspaper "the Observant", unknown to me before I came to Maastricht, but that since my appointment has found a fixed spot next to my bed.., wasn't it that newspaper that headlined in the first interview with me that "with the new rector exciting things will happen".

In my view Maastricht University has embarked many years ago on a path where exciting things are happening. I think of Brightlands, EDLAB, and the many interfaculty and interdisciplinary research institutes where groundbreaking research is taking place. But if you want something exciting from me, allow me to share with you my vision on diversity and dialogical leadership so that you get to know me a little bit more. 


\section{Diversity as a game changer}

Diversity for me has a multi-level meaning, and let me explain what I mean with this. When talking about diversity it is often related or limited to diversity within groups, with scientific studies showing that a mixed group of persons from different gender, ethnicity, age and culture has positive effects on the organizations' functioning. I believe this is certainly true, and there is still a lot of effort needed to achieve this, which I consider as the first level of diversity.

A second level of diversity relates to the scientific disciplines we study. We need to think how we can ensure that a diversity of disciplines and within these disciplines, different research themes can flourish. And indeed, we cannot do everything, but I consider this as a responsibility of all universities to see where we can work together to make sure that Dutch science across disciplines arrives where it belongs; at the top.

A third level relates to what we expect from our colleagues. I see too often that we want staff members to be the sheep with five feet as we say in Dutch. We need to excel in research, teaching, valorization, and for some also management and fundraising. How realistic is this? Although a university needs staff members that are good at all these issues, we cannot expect us to excel in all. I therefore plea for diversity also in the way we evaluate our work, where we acknowledge and stimulate various individual contributions that impact the work of the entire team. Key is considering research, education and generating knowledge impact as team work, where together, with each of our individual contributions, as dedicated and motivated academics, teachers and members of our valued support staff, we can make a difference for society.

These objectives are not easy to achieve, but they are by no means infeasible. I am a strong believer of dialogical leadership as a driver of diversity at all three levels. Dialogical leadership applies inclusiveness and transparency in decision making as key differentiating features. This means that we need to listen first, before we act. This fits well with another advice I got during my first meetings in Maastricht, namely to descend from "De Berg" and engage in a dialogue with people from all different levels and organizations within the university. I will follow this advice and I will join my colleagues Martin Paul and Nick Bos to make this a regular activity. Our motto is: if you cannot go to the Berg, the Berg will come to you.

I will strive for open-minded and if necessary tough discussions with constructive conclusions that stimulate transparent and clear decision-making. I also wish you to take up responsibility for your own success in life and I consider it my responsibility to invest in that personally. I want you to be open for discussion and show and ask respect and express admiration for each other both in person and in profession. The ambition to encourage strength and resilience are not just buzz words in strategic plans or words of a 'just appointed administrator'. I believe when truly investing in our staff and students, we will all grow, institutionally and individually.

In my weekly visits over the past three months, I have noticed a few remarkable things about Maastricht University that already reflect these ambitions. Unquestionably the university holds a beautiful location in the city of Maastricht where the many old buildings contrast the youthful spirit of its inhabitants. The warmth of the staff of the university I noticed as another asset of this university. 
Another thing I enjoyed very much are our students. They are vital and engaged and very active in a multifold of study and student activities. The slogan they chose for this year's welcoming week for the first year students, The Future is Now, I found magnificent.

\section{Taking ownership}

Having said that, I also see that universities are frequently in the focal point of attention because things are allegedly not going well. Governors and authorities are focusing too much of their attention on rankings and performance indicators. Employees complain about stress at work and feel frustrated by the enormous pressure they feel imposed on them by the university system. Students call for more participation and democracy, and want to be actively involved in the process of managing a university. Media feast on fraud cases and amplify any kind of academic abuse they notice. Society in general wants to know what universities can contribute on their account and call upon us for knowledge utilization.

It is my true conviction that universities can handle their problems by taking more ownership, not merely looking to The Hague or Brussels for guidance or instructions. By working on an attractive diversity profile that provides us with ample opportunities for both collective and individual developments, we can give universities a sound basis for the coming years to grow, without the need to adhere to strict performance targets or to get trapped by work pressure.

The question that remains is what should be that profile and how are we going to take ownership of it? For me this boils down to the following fundamental, almost existential, question "Why and for what purpose are we running this university?" This question calls for an open discussion on the scientific disciplines that we choose to study and to the way we want to educate our younger generations. Secondly, it relates to the discussion about the need and obligation to generate impact with our knowledge.

Also here, for me, diversity is the guiding principle, which means that, to give just two examples, we should value the work of scholars who wish to devote their time to purely curiosity driven research topics with its often long awaited output, whereas we should appreciate the longing of others to invest more time or to excel in what is often called applied research. Likewise, knowledge impact is not only about transferring knowledge into economic value, it also concerns non-monetary values and these should be appreciated accordingly.

\section{And finally}

For now I have said quite enough. Dear Martin, dear Nick, I am looking forward to serve with you on the board of governance and I wish to thank the members of the supervisory board, the management team of the university and the University Council for the faith entrusted on me. Dear colleagues at the Berg, thanks in particular also for making my first undercover months, such a pleasant experience.

I want to conclude by saying that I'm terribly excited to start this new job as a rector. With its strong international orientation, its well-chosen educational vision, its compelling research profile, and its wonderful staff and students, Maastricht University 
has stolen my heart and mind as of the first moment I arrived in March. I am honored to become part of your community.

Let us all try to be strong, innovative and resilient, and not to forget, optimistic, as life is too short to complain... or ... to repeat the slogan of our students: The Future is Now!

Thank you for your attention.

Prof.dr.mr. Rianne Letschert

Maastricht, September 1, 2016 